\title{
NASA homes in on sites for Mars exploration
}

Tony Reichhardt, Washington

After more than two years of deliberation, a committee of planetary scientists has picked the landing sites for NASA's two Mars Exploration Rovers, due to launch between May and July this year. The two locations - Gusev Crater and Meridiani Planum — have been chosen because of the high likelihood that water, and perhaps life, once existed there.

The rovers will use parachutes and protective airbags to bounce down on to the martian surface next January. Once deployed, they will spend at least three months rolling slowly from rock to rock, taking panoramic photographs and examining the local geology. Each rover is equipped with a high-resolution camera, a diamond-tipped grinder to expose fresh surfaces on dusty rocks, a microscopic imager to examine such surfaces, and three spectrometers to analyse the rocks' chemical make-up and mineral content.

Gusev's appeal has been obvious since the Viking orbiters took the first close-up pictures of Mars in the 1970s. The ancient impact crater shows strong evidence of once having been flooded with water because its bottom is flat and relatively smooth, like that of a lake bed, and a dry river channel seems to run into the structure at one end. Scientists first scrutinized the Meridiani site in 2000, when NASA's orbiting Mars Global Surveyor detected large deposits of the iron oxide mineral haematite. As most of the processes that form this mineral on Earth require water, its presence hints that water may have been present at the site in the past. Water is considered essential for life, and finding evidence of past biology is a priority for Mars exploration.

When the landing-site selection committee began work in 2000 , it had a list of 155 possibilities. These were quickly whittled down to seven top contenders, says John Grant, a planetary scientist at the Smithsonian Institution's National Air and Space Museum in Washington DC, who co-chaired the panel. Gusev and Meridiani have long been front-runners in terms of scientific merit, but they also had to satisfy several engineering constraints. The elevation of the landing site cannot be too high, for example, as the atmosphere needs to be dense enough for the parachutes to work. Boulders are a landing hazard and smaller rocks can impede the rovers, so the site must be reasonably free from such obstacles.

Questions still remain over another constraint. Project scientists will continue to refine their predictions of windiness at the Gusev site before NASA commits to landing there. NASA's last Mars lander — the 1997 Pathfinder mission - landed early in the

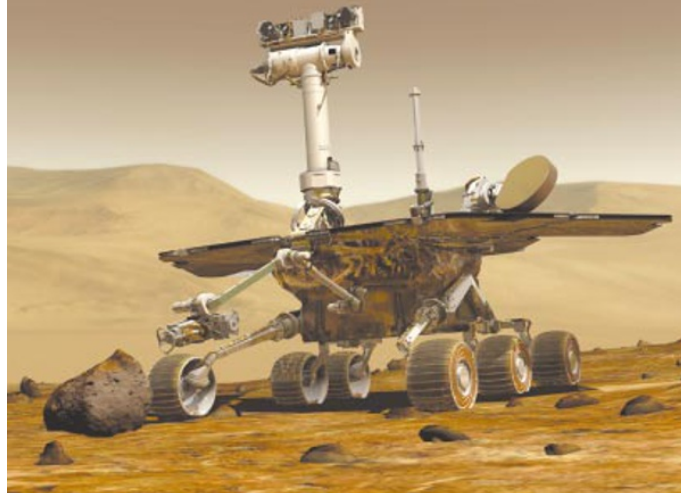

The wild rover: NASA is set to launch two probes to scour the surface of Mars for signs of life.

martian morning, when it was least windy. But to make sure that signals are sent to Earth during landing, the new rovers will touch down in mid-afternoon, when the winds are typically stronger and could tear the airbags designed to cushion their landing, says Grant.

NASA can make final decisions on the landing sites as much as a month after the first launch, currently scheduled for 30 May. The second rover will launch in late June. Both rovers will be given names before launch, based on suggestions from schoolchildren.

\section{Polish science academy prepares for radical overhaul}

\section{Quirin Schiermeier, Munich}

Winds of change are set to blow through the Polish Academy of Sciences, according to the plant biologist freshly elected to run the organization.

The academy — like many of its eastern European counterparts - oversees a large but somewhat dilapidated national network of research institutes in a range of disciplines. And although Poland has the largest and one of the strongest economies in the region, critics say that parts of the academy have not changed much since communist rule ended in 1989.

But this month Andrzej Legocki, a plant biologist and former director of the academy's Institute of Bioorganic Chemistry in Poznań, takes over as president. He says that he will commission an external quality review of all 80 of the institutes - and predicts that around ten of them could close once the review is completed later this year.

Legocki promises to tackle the academy's main problems head-on, including low output, ageing research staff and lack of contact with university research.

"I am determined to drastically change the situation," he says. "First we shall

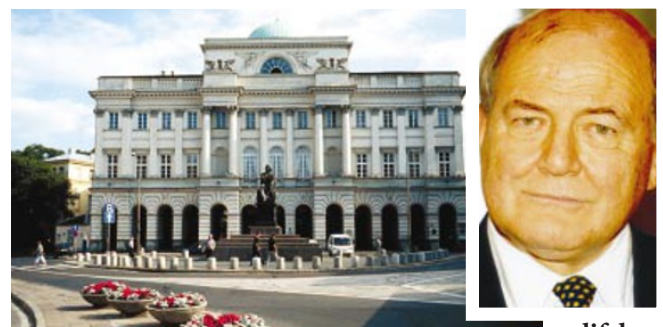

grassroots organization of European scientists, says that Polish science is in need of a drastic overhaul. "Poland is simply too poor to subsidize an oversized, mediocre science base," he says.

The academy employs about 4,000 scientists, mostly in permanent positions. Critics say that their lifelong job security gives them little incentive to be competitive. And Legocki concedes that the academy lags behind in many fields.

To boost the position of young scientists recognize what is worth maintaining, then we will merge groups and institutes, and put them under new, younger leadership." At 63, Legocki is himself the youngest president in the academy's 50-year history.

Poland is the largest of ten countries in central and eastern Europe that will join the European Union next year, but it has been slower than some others, notably Hungary and the Czech Republic, to reform its scientific infrastructure (see Nature 421, 471-472; 2003).

Jerzy Langer, a solid-state physicist at the academy's Institute of Physics in Warsaw and vice-president of Euroscience, a in the academy, Legocki pledges that all institutes that do not already have a graduate student programme will establish one, along with fixed-term postdoctoral positions for young researchers. "Young scientists at our institutes will be under my personal patronage," he promises.

"Legocki is the right man at the right time," says Jacek Kuźnicki, a neuroscientist and director of the International Institute of Molecular and Cell Biology in Warsaw. "But for any reform to be succesful it is vital the older generation accepts that competition is an essential part of the game." www.pan.pl/english/index1.htm 